\title{
Nekton use of marsh-surface habitats in Louisiana (USA) deltaic salt marshes undergoing submergence
}

\author{
Lawrence P. Rozas ${ }^{*}$, Denise J. Reed \\ Louisiana Universities Marine Consortium, Marine Research and Education Center, Chauvin, Louisiana 70344, USA
}

\begin{abstract}
We used lift nets from April through November 1991 in Louisiana (USA) deltaic marshes to compare nekton densities in 3 marsh-surface habitats undergoing submergence and having different surface elevations (Distichlis spicata marsh = high elevation; intact Spartina alterniflora marsh $=$ intermediate elevation; and hummocky $S$. alterniflora marsh = low elevation). Daggerblade grass shrimp Palaemonetes pugio, gulf killifish Fundulus grandis, sheepshead minnow Cyprinodon variegatus, diamond killifish Adinia xenica, striped mullet Mugil cephalus, blue crab Callinectes sapidus, brown shrimp Pendeus aztecus, and white shrimp $P$. setiferus numerically dominated samples from all 3 marsh types and accounted for $93 \%$ of the total catch. These dominant species exhibited 3 distinct patterns of spatial distribution among habitats. Gulf killifish and diamond killifish were most abundant on $D$. spicata marsh, whereas highest densities of brown shrimp and white shrimp were found on hummocky S. alterniflora marsh. Densities of daggerblade grass shrimp, sheepshead minnows, striped mullet, and blue crabs were similar among the 3 marsh types. Although in an advanced state of deterioration, hummocky S. alterniflora marsh did not lose its habitat function. Submergence of coastal Gulf of Mexico marshes may benefit marsh nekton, especially penaeid shrimp, by increasing the percentage of time the marsh surface is available for use. However, these benefits will be short-lived in regions where rapid submergence leads to a significant decrease in total marsh habitat.
\end{abstract}

\section{INTRODUCTION}

The loss of wetlands caused by coastal submergence is a serious problem in many regions of the United States (Gornitz et al. 1982, Clark 1986, Stevenson et al. 1986, Hackney \& Cleary 1987). In Louisiana, the highest rate of coastal land loss occurs in the Mississippi River deltaic plain, where between 1983 and 1990 land was converted to open water at an average rate exceeding $50 \mathrm{~km}^{2} \mathrm{yr}^{-1}$ (Dunbar et al. 1992). The Mississippi River deltaic plain consists of a series of overlapping Holocene deltas which have been sequentially built up and then abandoned by the river as it changed its course to the Gulf of Mexico (Coleman \& Gagliano 1964). A major cause of the current land loss

\footnotetext{
- Present address: NOAA/National Marine Fisheries Service, Southeast Fisheries Science Center, 4700 Avenue U, Galveston, Texas 77551-5997, USA
}

problem was the leveeing of the Mississippi River and the channelizing and stabilizing of its outlet in the early part of this century, which severely curtailed freshwater and sediment inputs to the deltaic marshes (Baumann et al. 1984). New sediment is no longer supplied by the river during spring floods, and the abandoned Holocene deltaic deposits are rapidly subsiding. Consequently, deltaic marshes in coastal Louisiana are experiencing a relative sea level rise of approximately $1 \mathrm{~cm} \mathrm{yr}^{-1}$ (Penland \& Ramsey 1990). As subsidence proceeds, marsh sediments become waterlogged, stressing marsh vegetation and reducing net primary productivity (Mendelssohn \& McKee 1988). Where subsidence continues without compensating marshsurface accretion, waterlogging leads to a buildup of toxic sulfides in sediments, which eventually causes plant death (Mendelssohn \& McKee 1988).

In salt marshes undergoing submergence, the process of vegetation deterioration and conversion of 
marsh to open water is gradual. Deterioration usually begins in the marsh interior (Smith 1970, Sasser et al. 1986, Mendelssohn \& McKee 1988) where sediment accretion rates are less than at streamside locations (Baumann \& DeLaune 1982, Hatton et al. 1983), and submergence is therefore increased. As more and more plants die, the character of the marsh surface changes from uniform, intact stands of vegetation to bare substrate interspersed by small patches of vegetation. In these bare areas where vegetation is no longer present to bind the substrate, to trap new sediment, or to add below-ground biomass, the rate of submergence accelerates. Eventually, the marsh surface takes on a hummocky appearance as the difference in surface elevation between vegetated patches and bare substrate becomes pronounced. In the final stage of deterioration bare areas deepen, expand, and merge to form ponds (Sasser et al. 1986). Ultimately, large areas that were once vegetated intertidal habitat (salt marsh) are converted into shallow, unvegetated subtidal environments.

Estuarine marshes provide nursery habitat for numerous species of nekton (Zimmerman \& Minello 1984, Rozas \& Odum 1987, Mclvor \& Odum 1988, Hettler 1989, Kneib 1991, Rozas 1992b), and many of the species that depend on these marshes support important coastal fisheries. For example, brown shrimp Penaeus aztecus Ives are dependent on marsh-surface habitat during their postlarval and early juvenile stages (Minello \& Zimmerman 1991). Blue crabs Callinectes sapidus Rathbun and striped mullet Mugil cephalus Linnaeus also use the marsh surface as small juveniles (Hettler 1989, Thomas et al. 1990, Rozas 1992a). In addition, this habitat is essential for forage species such as grass shrimp and killifishes, which are eaten by predatory fishery species, and therefore support fishery stocks through the food chain.

Although the use of coastal marshes by nekton is well documented, we know very little about how habitat use might change as coastal marshes undergo submergence and deterioration. The purpose of our research was to document patterns of nekton use among salt marsh habitats in a region of coastal Louisiana undergoing rapid submergence. Nekton densities were quantified and compared among 3 adjacent marsh-surface habitats having different elevations.

\section{MATERIALS AND METHODS}

The study area was within the Terrebonne-Timbalier estuary near latitude $29^{\circ} 14^{\prime} \mathrm{N}$ and longitude $90^{\circ} 40^{\prime}$ W. approximately $4 \mathrm{~km}$ southwest of the Louisiana Universities Marine Consortium (LUMCON) Marine Center at Cocodrie (Fig. 1). Tides in the estuary are predominantly diurnal and have a mean range of approximately $0.4 \mathrm{~m}$ (Shirzad et al. 1989, U.S. Department of Commerce 1990). Chabreck \& Linscombe (1991) classified the area as saline marsh. Spartina alterniflora Loisel dominated the vegetation except at higher elevations (e.g. on natural levees of tidal creeks) where Distichlis spicata (L.) Greene grew in dense stands.

Along each of 3 natural channels $(A, B$, and $C$; Fig. 1), we selected 3 marsh types having different surface elevations: Distichlis spicata marsh was highest in elevation; intact Spartina alterniflora marsh was intermediate in elevation; and hummocky $S$. alterniflora marsh was lowest in elevation. We surveyed surface el-

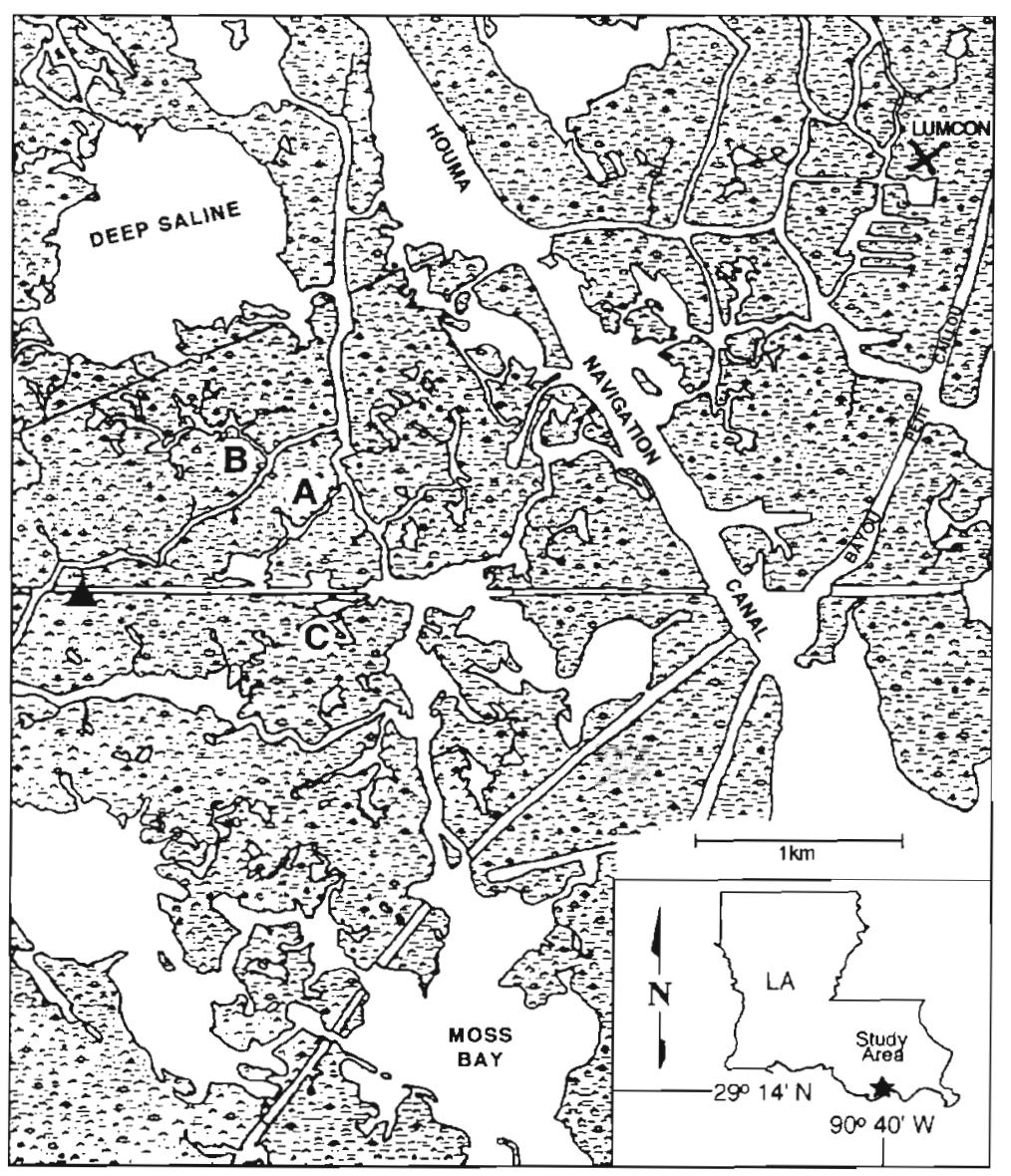

Fig. 1 Study area showing its location relative to Louisiana. Marsh sampling sites were located along Channels A, B, and C. (4) Location of water level recorder 
evations of sites in relation to local benchmarks and staff gauges located on each channel; these were tied into the National Oceanic and Atmospheric Administration/National Ocean Service (NOAA/NOS, Rockville, Maryland 20852) Cocodrie tide station (No. 876-2928) at the LUMCON Marine Center. In addition, a water level recorder was installed in a pipeline canal near the study sites in September 1991 (Fig. 1). Elevation data and tide gauge records were used with a software package, PEAKBASE, to calculate duration of marsh flooding (Reed \& Cahoon 1992). We also measured plant-stem density within each sampling area in October 1991, near the period of peak standing crop (Hopkinson et al. 1978), and the distance from each site to the channel. When sampling nekton, we measured water temperature and salinity in the channels adjacent to each site with a Beckman RS5-3 salinometer.

Sampling. We sampled nekton on marshes using 9 lift nets (Rozas 1992a), one in each marsh type along the 3 channels. Briefly, lift nets $(2 \times 3 \times 1 \mathrm{~m}$ deep) were bottomless with walls constructed of $3 \mathrm{~mm}$ mesh nylon netting. Between sampling events the net walls were buried in the marsh substrate. To collect a sample at slack high tide, 2 persons simultaneously pulled the net walls into an upright position from remote locations, trapping organisms inside the enclosed area. As the marsh drained, organisms accumulated in a collecting pan located in one corner of each sampling area. We retrieved samples at low tide by temporarily removing each collecting pan and placing its contents into a sample bag. We collected nekton at each sample site on 15 occasions from April through November
1991: once in April, May, and October; twice in August, September, and November; and 3 times in June and July. Sampling occurred on tropical tides to insure that marshes at all sites were flooded. In July, the 3 lift nets on Channel B had to be moved about $100 \mathrm{~m}$, outside an area of vegetation dieoff. The cause of the vegetation dieoff is unknown, but it followed a period of unusually high tides in the spring of 1991. Prolonged flooding of the area may have caused sufficient waterlogging of the marsh soils to kill the vegetation.

Samples were preserved in $20 \%$ formalin for at least $72 \mathrm{~h}$, washed in running water for $24 \mathrm{~h}$, and placed into $70 \%$ ethanol for storage. Organisms were later separated from detritus, identified to species, and counted. All individuals of each species in a sample were weighed together to the nearest $0.1 \mathrm{~g}$ (wet weight).

Statistical analyses. Our statistical design was a repeated measures multivariate analysis of variance (MANOVA) with the lift net the unit of observation (O'Brien \& Kaiser 1985, Norusis 1990). The betweensubjects factor was elevation or marsh type, the withinsubjects factor was sampling date. Data for each numerically dominant species were analyzed for differences in catch (number of individuals) among marsh habitats. Catch data were $\ln (x+1)$-transformed prior to analyses to meet the MANOVA assumption of homogeneity of variances (Green 1979). When significant results were found among treatments, the data were analyzed with a posteriori contrasts (Norusis 1990). A significance level of 0.10 was used for a posteriori contrasts to increase the power of this analysis, and 0.05 was used for all other analyses; these values

Table 1. Characteristics of lift-net sites in Distichlis spicata and Spartina alterniflora marsh. Elevations are based on a Mean Tide Level of $95.1 \mathrm{~cm}$ (3.12 ft.) for the NOAA Cocodrie tide station located at the LUMCON Marine Center. Distances were measured from the edge of the net to the nearest tidal channel. B2 sites replaced B1 sites in July 1991

\begin{tabular}{|lccc|}
\hline Site & $\begin{array}{c}\text { Elevation above } \\
\text { Mean Tide Level } \\
(\mathrm{cm})\end{array}$ & $\begin{array}{c}\text { Distance to } \\
\text { channel } \\
(\mathrm{m})\end{array}$ & $\begin{array}{c}\text { Stem density } \\
\left.\text { (culms per } 0.062 \mathrm{~m}^{2}\right)\end{array}$ \\
\hline A D. spicata & 20.4 & 1.7 & 58 \\
A Intact S. alterniflora & 11.3 & 4.1 & 23 \\
A Hummocky S. alterniflora & 4.3 & 3.3 & 19 \\
B1 D. spicata & 17.1 & 11.8 & - \\
B1 S. alterniflora & 13.4 & 13.6 & - \\
B1 S. alterniflora & 3.4 & 22.5 & 75 \\
B2 D. spicata & 20.7 & 3.5 & 17 \\
B2 Intact S. alterniflora & 13.1 & 4.8 & 9 \\
B2 Hummocky S. alterniflora & 7.6 & 7.0 & 32 \\
C D. spicata & 14.6 & 3.6 & 8 \\
C Intact S. alterniflora & 13.7 & 4.9 & 3 \\
C Hummocky S. alterniflora & 7.0 & 3.0 & \\
\hline
\end{tabular}




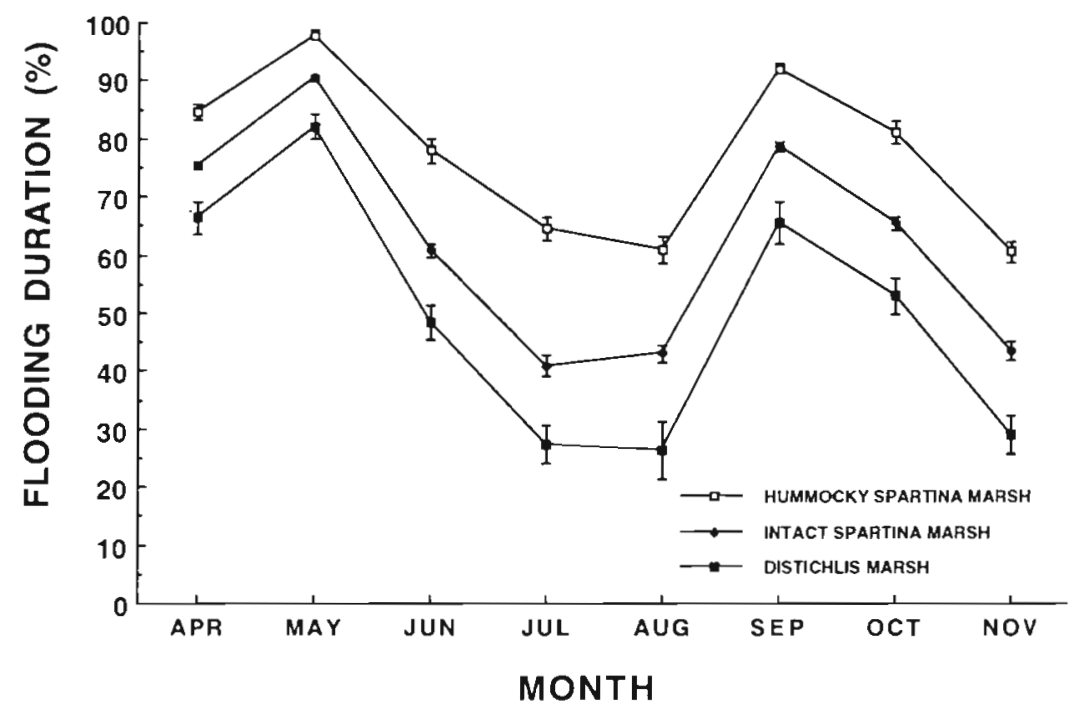

Fig. 2. Average monthly flooding durations [(hours marsh inundated)/ (total hours in month) $\times 100$ ] of Distichlis spicata, intact Spartina alterniflora, and hummocky S. alterniflora marshes from April to November 1991 Error bars

$$
=1 \mathrm{SE}
$$

were adjusted using the method of Rice (1989) to correct for the error introduced by making multiple statistical comparisons.

\section{RESULTS}

Distichlis spicata marsh contained the greatest density of plants and was on average 5 and $13 \mathrm{~cm}$ higher than intact and hummocky Spartina alterniflora marshes, respectively. Hummocky S, alterniflora

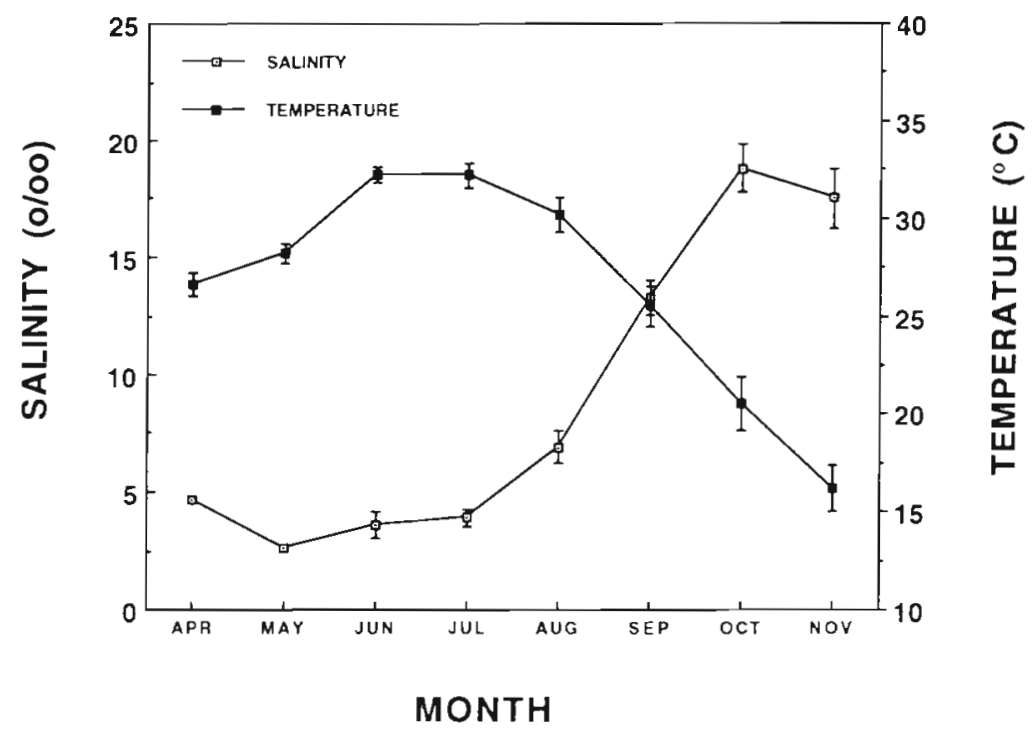

Fig. 3. Average monthly salinity and water temperature (all sample sites combined), Aprll to November 1991 Error bars = $1 \mathrm{SE}$ marsh, which was in an advanced stage of submergence and vegetation deterioration, generally contained the sparsest vegetation and was approximately $7 \mathrm{~cm}$ lower than intact $S$. alterniflora marsh (Table 1).

Data obtained from our 2 sources of water-level records were coherent for the 3 months in which both collected data $\left(R^{2}\right.$ : Sep $=0.80$, Oct $=0.93$, Nov $=$ 0.83). Because the LUMCON gauge provided water-level data for the entire study period, we used data from it to estimate flooding duration of study marshes. Flooding durations differed substantially among marshes, even though elevational differences were relatively small. For example, Distichlis spicata marsh flooded $<30 \%$ of the time during July, August and November, and $<55 \%$ of the time in 5 of the 8 months it was sampled, whereas hummocky Spartina alterniflora marsh was inundated more than $60 \%$ of the time during each month (Fig. 2). The average water temperature peaked in the summer months $\left(32{ }^{\circ} \mathrm{C}\right.$ in June and July); lowest temperatures occurred in November (Fig 3). Above-average rainfall in the spring kept salinities below $5 \%$ well into summer, but salinity in the area increased to $18.8 \%$ in October (Fig. 3).

In 135 lift-net samples we collected 8229 organisms having a preserved wet weight of $14.3 \mathrm{~kg}$. We identified 25 species (13 families) of fishes and 4 species ( 3 families) of decapod crustaceans from these samples (Table 2). Daggerblade grass shrimp Palaemonetes pugio Holthuis, gulf killifish Fundulus grandis Baird \& Girard, sheepshead minnow Cyprinodon variegatus Lacepede, diamond killifish Adinia xenica (Jordan \& Gilbert), striped mullet, blue crab, brown shrimp, and white shrimp Penaeus setiferus (Linnaeus) numerically dominated catches and accounted for 93 and $95 \%$ of the total catch and biomass, respectively (Table 2 )

The spatial distribution of nekton on marshes varied with species, but 3 distinct patterns were observed. Four species showed a preference for either Distichlis spicata marsh or hummocky Spartina alterniflora marsh (Fig. 4). Gulf killifish and diamond killifish were most abundant on $D$. spicata marsh (Tables $3,4 \& 5$, Fig. 4), and were occasionally collected on marshes inundated as little as $5 \mathrm{~cm}$ deep. 
Table 2. List of fishes and decapod crustaceans collected on Distichlis spicata and Spartina alterniflora marsh surface from April to November 1991 using lift nets. Total number and biomass (g wet wt, in parentheses) for each marsh type represent pooled data for 45 samples of $6 \mathrm{~m}^{2}$ each. Relative abundance and biomass for all marsh types combined are given only when equal to at least $1 \%$

\begin{tabular}{|c|c|c|c|c|}
\hline \multirow[t]{2}{*}{ Scientific and common name } & \multicolumn{3}{|c|}{ Totals by habitat } & \multirow{2}{*}{$\begin{array}{c}\text { Relative } \\
\text { abundance and } \\
\text { biomass } \\
(\%)\end{array}$} \\
\hline & D. spicata & $\begin{array}{l}\text { Intact } \\
\text { S. alterniflora }\end{array}$ & $\begin{array}{l}\text { Hummocky } \\
\text { S. alterniflora }\end{array}$ & \\
\hline $\begin{array}{l}\text { Palaemonetes pugio Holthuis } \\
\text { Daggerblade grass shrimp }\end{array}$ & $\begin{array}{c}1052 \\
(166.5)\end{array}$ & $\begin{array}{c}540 \\
(82.9)\end{array}$ & $\begin{array}{c}1461 \\
(219.5)\end{array}$ & $\begin{array}{r}37.1 \\
3.3\end{array}$ \\
\hline $\begin{array}{l}\text { Fundulus grandis Baird \& Girard } \\
\text { Gulf killifish }\end{array}$ & $\begin{array}{c}1069 \\
(2028.2)\end{array}$ & $\begin{array}{c}234 \\
(575.8)\end{array}$ & $\begin{array}{c}128 \\
(264.3)\end{array}$ & $\begin{array}{l}17.4 \\
20.0\end{array}$ \\
\hline $\begin{array}{l}\text { Cyprnnodon variegatus Lacepede } \\
\text { Sheepshead minnow }\end{array}$ & $\begin{array}{c}604 \\
(696.3)\end{array}$ & $\begin{array}{c}281 \\
(390.9)\end{array}$ & $\begin{array}{c}88 \\
(76.1)\end{array}$ & $\begin{array}{r}11.8 \\
8.1\end{array}$ \\
\hline $\begin{array}{l}\text { Adinia xenica (Jordan \& Gilbert) } \\
\text { Diamond killifish }\end{array}$ & $\begin{array}{c}418 \\
(130.9)\end{array}$ & $\begin{array}{c}216 \\
(88.4)\end{array}$ & $\begin{array}{c}84 \\
(29.4)\end{array}$ & $\begin{array}{l}8.7 \\
1.7\end{array}$ \\
\hline $\begin{array}{l}\text { Mugil cephalus Linnaeus } \\
\text { Striped mullet }\end{array}$ & $\begin{array}{c}107 \\
(909.9)\end{array}$ & $\begin{array}{c}239 \\
(1937.3)\end{array}$ & $\begin{array}{c}253 \\
(1338.5)\end{array}$ & $\begin{array}{r}7.3 \\
29.2\end{array}$ \\
\hline $\begin{array}{l}\text { Callinectes sapidus Rathbun } \\
\text { Blue crab }\end{array}$ & $\begin{array}{c}205 \\
(2298.1)\end{array}$ & $\begin{array}{c}103 \\
(1004.0)\end{array}$ & $\begin{array}{c}168 \\
(992.5)\end{array}$ & $\begin{array}{r}5.8 \\
30.0\end{array}$ \\
\hline $\begin{array}{l}\text { Penaeus aztecus Ives } \\
\text { Brown shrimp }\end{array}$ & $\begin{array}{c}28 \\
(27.5)\end{array}$ & $\begin{array}{c}51 \\
(48.6)\end{array}$ & $\begin{array}{c}140 \\
(126.7)\end{array}$ & $\begin{array}{l}2.7 \\
1.4\end{array}$ \\
\hline $\begin{array}{l}\text { Penaeus setiferus (Linnaeus) } \\
\text { White shrimp }\end{array}$ & $\begin{array}{c}7 \\
(1.9)\end{array}$ & $\begin{array}{c}39 \\
(25.7)\end{array}$ & $\begin{array}{c}167 \\
(117.1)\end{array}$ & $\begin{array}{l}2.6 \\
1.0\end{array}$ \\
\hline $\begin{array}{l}\text { Menidia beryllina (Cope) } \\
\text { Inland silverside }\end{array}$ & $\begin{array}{c}27 \\
(24.3)\end{array}$ & $\begin{array}{c}117 \\
(58.5)\end{array}$ & $\begin{array}{c}45 \\
(35.8)\end{array}$ & $\begin{array}{c}2.3 \\
-\end{array}$ \\
\hline $\begin{array}{l}\text { Fundulus pulvereus (Evermann) } \\
\text { Bayou killifish }\end{array}$ & $\begin{array}{c}98 \\
(76.6)\end{array}$ & $\begin{array}{l}10 \\
(5.8)\end{array}$ & $\begin{array}{c}7 \\
(3.4)\end{array}$ & 1.4 \\
\hline $\begin{array}{l}\text { Fundulus similis (Baird \& Girard) } \\
\text { Longnose killifish }\end{array}$ & $\begin{array}{c}70 \\
(48.2)\end{array}$ & $\begin{array}{c}20 \\
(46.8)\end{array}$ & $\begin{array}{c}1 \\
(0.0)\end{array}$ & 1.1 \\
\hline $\begin{array}{l}\text { Gobiosoma bosc (Lacepede) } \\
\text { Naked goby }\end{array}$ & $\begin{array}{c}6 \\
(2.8)\end{array}$ & $\begin{array}{c}14 \\
(9.0)\end{array}$ & $\begin{array}{c}23 \\
(9.3)\end{array}$ & - \\
\hline $\begin{array}{l}\text { Evorthodus lyricus (Girard) } \\
\text { Lyre goby }\end{array}$ & $\begin{array}{c}15 \\
(23.0)\end{array}$ & $\begin{array}{c}8 \\
(23.9)\end{array}$ & $\begin{array}{c}18 \\
(32.3)\end{array}$ & - \\
\hline $\begin{array}{l}\text { Gobionellus shufeldti (Jordan \& Eigenmann) } \\
\text { Freshwater goby }\end{array}$ & $\begin{array}{c}8 \\
(2.1)\end{array}$ & $\begin{array}{c}3 \\
(1.5)\end{array}$ & $\begin{array}{c}5 \\
(1.3)\end{array}$ & - \\
\hline $\begin{array}{l}\text { Poecilia latipinna (Lesueur) } \\
\text { Sailfin molly }\end{array}$ & $\begin{array}{c}4 \\
(5.7)\end{array}$ & $\begin{array}{c}3 \\
(1.8)\end{array}$ & $\begin{array}{c}8 \\
(5.1)\end{array}$ & - \\
\hline $\begin{array}{l}\text { Bairdiella chrysoura (Lacepede) } \\
\text { Silver perch }\end{array}$ & $\begin{array}{c}2 \\
(0.1)\end{array}$ & $\begin{array}{c}0 \\
(0.0)\end{array}$ & $\begin{array}{c}5 \\
(8.2)\end{array}$ & - \\
\hline $\begin{array}{l}\text { Cynoscion nebulosus (Cuvier) } \\
\text { Spotted seatrout }\end{array}$ & $\begin{array}{c}2 \\
(13.1)\end{array}$ & $\begin{array}{c}1 \\
(56.5)\end{array}$ & $\begin{array}{c}3 \\
(13.5)\end{array}$ & - \\
\hline $\begin{array}{l}\text { Myrophis punctatus Lutken } \\
\text { Speckled worm eel }\end{array}$ & $\begin{array}{c}3 \\
(57.3)\end{array}$ & $\begin{array}{c}1 \\
(37.8)\end{array}$ & $\begin{array}{c}0 \\
(0.0)\end{array}$ & - \\
\hline $\begin{array}{l}\text { Citharichthys spilopterus Gunther } \\
\text { Bay whiff }\end{array}$ & $\begin{array}{c}0 \\
(0.0)\end{array}$ & $\begin{array}{c}0 \\
(0.0)\end{array}$ & $\begin{array}{c}3 \\
(13.5)\end{array}$ & - \\
\hline $\begin{array}{l}\text { Fundulus jenkinsi (Evermann) } \\
\text { Saltmarsh topminnow }\end{array}$ & $\begin{array}{c}1 \\
(0.1)\end{array}$ & $\begin{array}{c}2 \\
(0.6)\end{array}$ & $\begin{array}{c}0 \\
10.0)\end{array}$ & - \\
\hline $\begin{array}{l}\text { Gobionellus boleosoma (Jordan \& Gilbert) } \\
\text { Darter goby }\end{array}$ & $\begin{array}{c}3 \\
(0.9)\end{array}$ & $\begin{array}{c}0 \\
(0.0)\end{array}$ & $\begin{array}{c}0 \\
(0.0)\end{array}$ & - \\
\hline $\begin{array}{l}\text { Lucania parva (Baird \& Girard) } \\
\text { Rainwater killifish }\end{array}$ & $\begin{array}{c}0 \\
(0.0)\end{array}$ & $\begin{array}{c}0 \\
(0.0)\end{array}$ & $\begin{array}{c}3 \\
(4.5)\end{array}$ & - \\
\hline $\begin{array}{l}\text { Dormitator maculatus (Bloch) } \\
\text { Fat sleeper }\end{array}$ & $\begin{array}{c}2 \\
(21.1)\end{array}$ & $\begin{array}{c}0 \\
(0.0)\end{array}$ & $\begin{array}{c}0 \\
(0.0)\end{array}$ & - \\
\hline $\begin{array}{l}\text { Archosargus probatocephalus (Walbaum) } \\
\text { Sheepshead }\end{array}$ & $\begin{array}{c}0 \\
(0.0)\end{array}$ & $\begin{array}{c}0 \\
(0.0)\end{array}$ & $\begin{array}{c}1 \\
(2.7)\end{array}$ & - \\
\hline
\end{tabular}


Table 2 (continued)

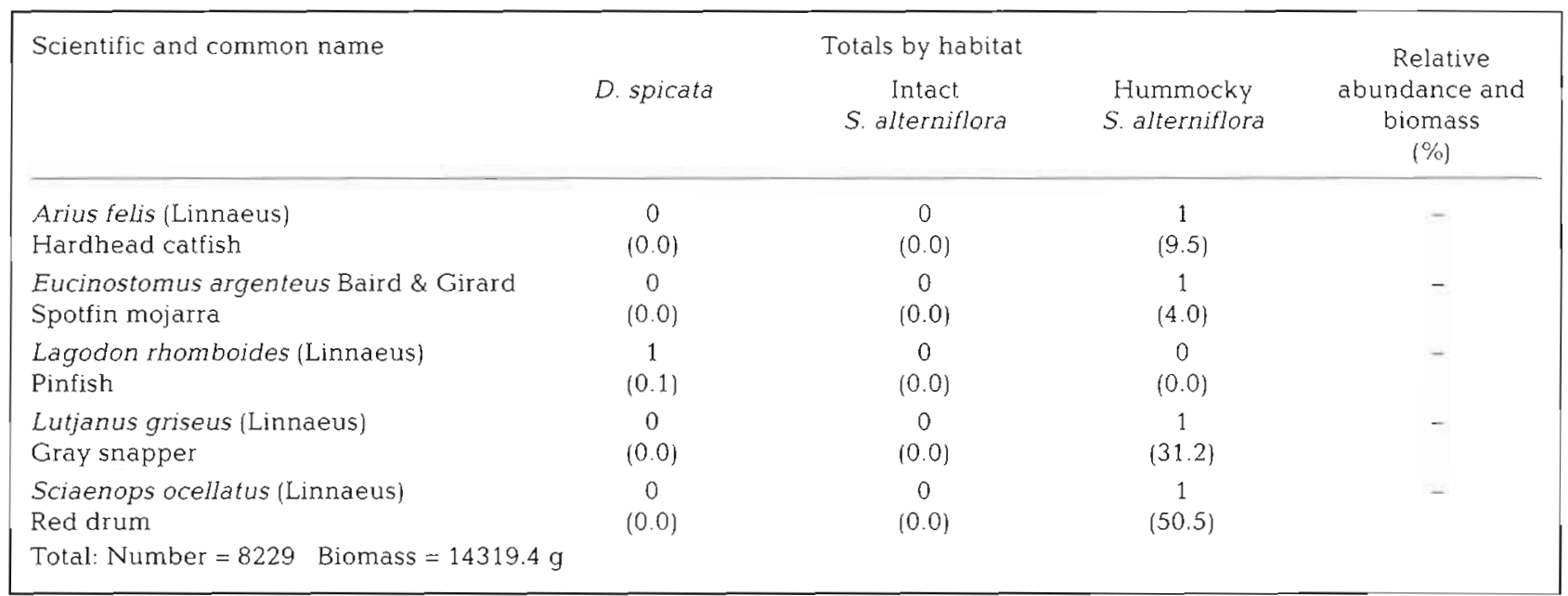
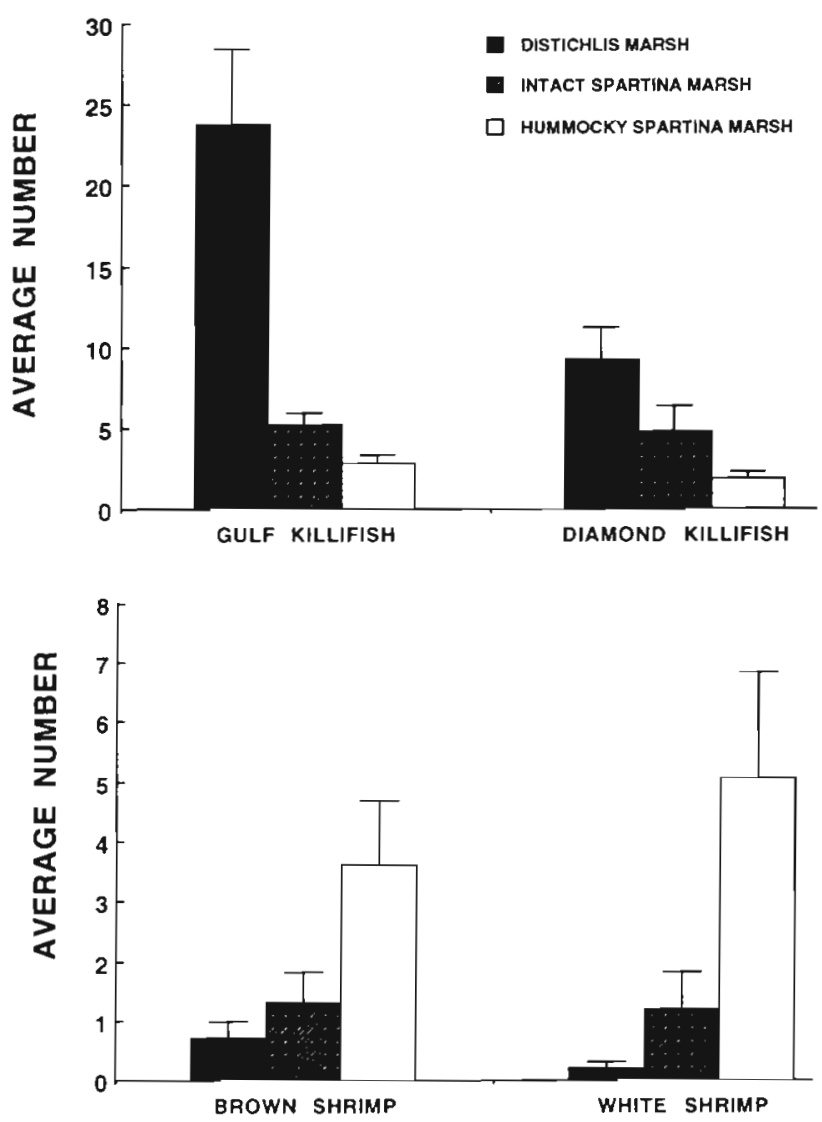

Fig. 4. Average number of gulf killifish Fundulus grandis, diamond killifish Adinia xenica, brown shrimp Penaeus aztecus, and white shrimp Penaeus setiferus collected in $6 \mathrm{~m}^{2}$ samples on the 3 marsh types. Means for gulf killifish and diamond killifish are calculated from 45 samples collected from April to November 1991. Means for brown shrimp and white shrimp are calculated from 39 samples (April to October 1991) and 33 samples (June to October 1991), respectively. Samples taken during months when penaeids were not collected in marsh habitats were not used to calculate means for these species. Error bars $=1 \mathrm{SE}$
In contrast to these killifishes, brown shrimp and white shrimp were found in greatest densities on hummocky S. alterniflora marsh (Tables 3,4 \& 5, Fig. 4), and penaeids were never collected on any marsh flooded $<10 \mathrm{~cm}$ deep. Densities of daggerblade grass shrimp, sheepshead minnow, striped mullet, and blue crab were not significantly different among marsh types (Tables $3 \& 4$ ).

Most of the dominant marsh nekton reached peak abundance in late summer to early fall (Table 3). However, white shrimp and gulf killifish were most numerous later in the year (September-October). Only 2 species, brown shrimp and daggerblade grass shrimp, were seasonally abundant on marshes in the spring.

\section{DISCUSSION}

Salt marshes undergoing submergence, even marshes in an advanced state of vegetation deterioration, continue to provide habitat for estuarine species. The process of submergence not only enhances access to the marsh surface, but it may also improve marsh habitat, at least over the short term, for some species. In our study both brown shrimp and white shrimp were strongly associated with hummocky Spartina alterniflora marsh (Fig, 4, Tables 3, 4 \& 5), a habitat-type characteristic of Gulf coast salt marshes in a late stage of submergence. Rather than moving into the shallowest habitat available, penaeid shrimp selected the lowelevation $S$. alterniflora marsh. Zimmerman \& Minello (1984) reported densities even higher than those reported here for penaeids and other decapods on a similarly deteriorated S. alterniflora marsh near Galveston Bay (Texas, USA). Selectively exploiting deteriorated marshes may have several advantages. Because they are lower in elevation, they are flooded deeper and 


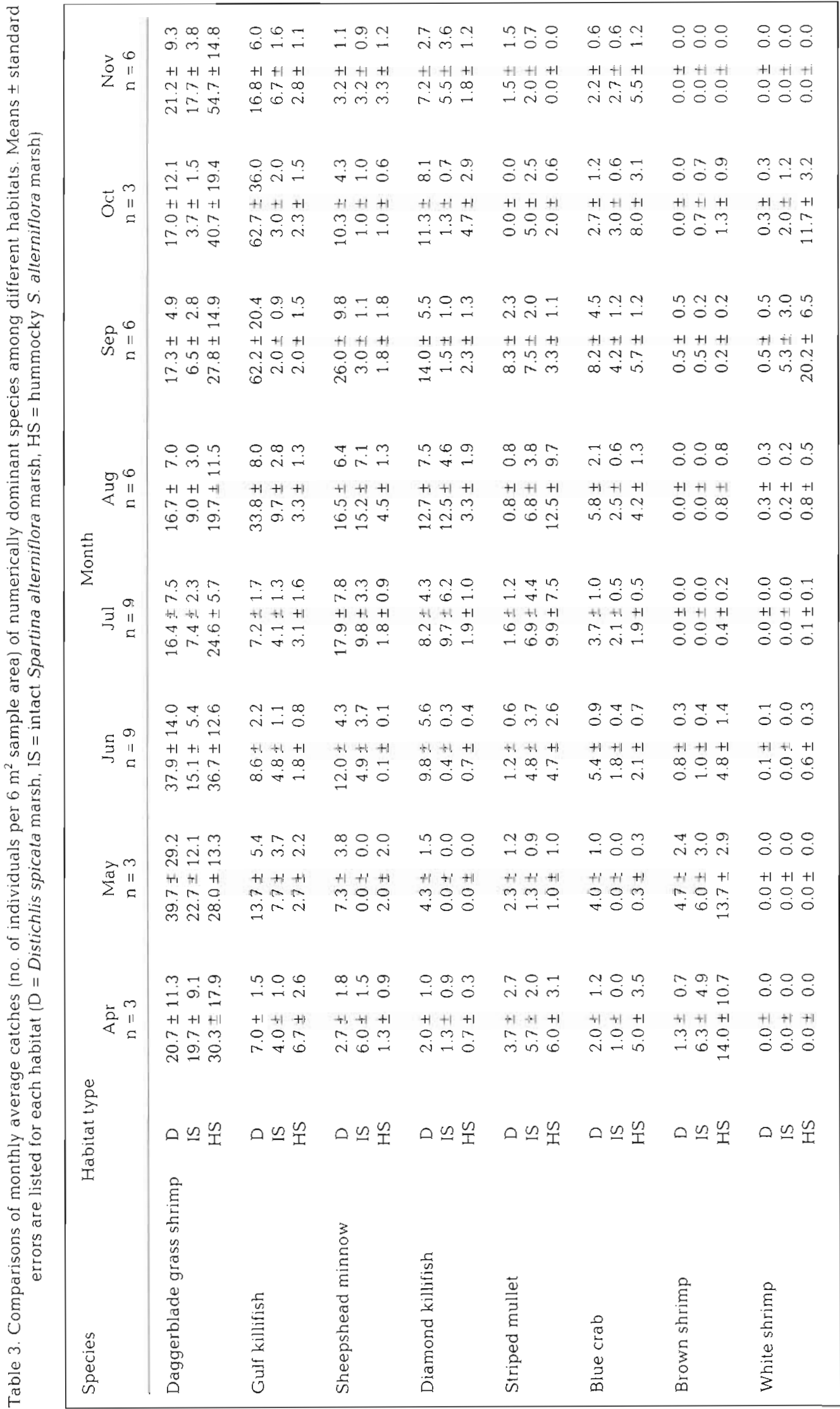


Table 4. Results of the MANOVA tests of differences in catch among habitats for the April to November 1991 sampling period. 'Significant result (adjusted $p<0.05$ as described by Rice 1989)

\begin{tabular}{|lccc|}
\hline Species & df & $F$ & Sig. of $F$ \\
\hline Gulf killifish & 2,4 & 78.82 & $0.001^{\circ}$ \\
White shrimp & 2,4 & 28.04 & $0.004^{\circ}$ \\
Diamond killifish & 2.4 & 21.06 & $0.008^{\circ}$ \\
Brown shrimp & 2.4 & 18.51 & $0.010^{\circ}$ \\
Sheepshead minnow & 2,4 & 11.16 & 0.023 \\
Blue crab & 2,4 & 4.43 & 0.097 \\
Daggerblade grass shrimp & 2,4 & 1.80 & 0.277 \\
Striped mullet & 2,4 & 0.83 & 0.500 \\
& & & \\
\hline
\end{tabular}

Table 5. Results of the MANOVA a posteriori comparisons of mean catches among habitats $(\mathrm{D}=$ Distichlis spicata, $\mathrm{IS}=$ Intact Spartina alterniflora, $\mathrm{HS}=$ hummocky S. alterniflora) for the April to November 1991 sampling period. - Significant result (adjusted $p<0.10$ as described by Rice 1989)

\begin{tabular}{|llccc|}
\hline Species & Comparison & df & $F$ & Sign. of $F$ \\
\hline Gulf killifish & D vs IS & 1,2 & 183.14 & $0.005^{\circ}$ \\
& D v HS & 1,2 & 77.24 & $0.013^{\circ}$ \\
Diamond killifish & D vs IS & 1,2 & 32.29 & $0.030^{\circ}$ \\
& D vs HS & 1,2 & 24.62 & $0.038^{\circ}$ \\
White shrimp & HS vs D & 1,2 & 66.58 & $0.015^{\circ}$ \\
\multirow{2}{*}{ Brown shrimp } & HS vs IS & 1,2 & 16.03 & $0.057^{\circ}$ \\
& HS vs D & 1,2 & 20.23 & $0.046^{\circ}$ \\
& HS vs IS & 1,2 & 18.68 & $0.050^{\circ}$ \\
\hline
\end{tabular}

National Marine Fisheries Service, Galveston Laboratory, pers. comm.). Brown shrimp may have been drawn to hummocky Spartina alterniflora marsh by high densities of this favored prey. Marsh hydroperiod also influences the species diversity and density of vegetation, which in turn may affect habitat quality. For example, S. alterniflora stem density decreases in subsiding marshes as hydroperiod increases (Linthurst \& Seneca 1980, Mendelssohn \& Seneca 1980). Scattered patches of $S$. alterniflora culms are less of an impediment to swimming organisms than thick vegetation, and sparse vegetation may provide more foraging surface and interfere less with the foraging activity of penaeid shrimp and other predators (Vince et al. 1976, Van Dolah 1978). Controlled experiments are now needed to further elucidate the specific mechanisms by which changes in hydroperiod alter the habitat function of $S$. alterniflora marshes.

Variations in hydroperiod may also influence differences in marsh-nekton densities on a regional scale. Zimmerman et al. (1991) have postulated that nekton exploit Gulf coast marshes in greater numbers than Southeastern U.S. Atlantic coast marshes, because Gulf coast marshes have longer hydroperiods. Quantitative estimates of nekton densities on Gulf and Atlantic coast marshes are few, but the available data are consistent with the hypothesis of greater marsh longer than other marsh habitats (Fig. 2). Therefore, deteriorated marsh is accessible for longer periods than higher marsh, giving penaeids more time to forage and find concealment from predators. Even sparse vegetation, which is characteristic of this habitat, may afford more protection from avian and large natant predators than bare substrate (Minello \& Zimmerman 1983, Minello et al. 1989)

A lengthy hydroperiod not only allows more time for marsh-surface exploitation, but it also influences the demsity of prey organisms found on marshes (Kneib 1984). For example, in the intertidal. zone, the spionid polychaete Streblospio benedicti Webster occurs most abundantly in low, frequently flooded areas (Kneib 1984, Rader 1984, LaSalle \& Rozas 1991), and it is a preferred prey of brown shrimp foraging on Gulf coast salt marshes (T. A. McTigue,

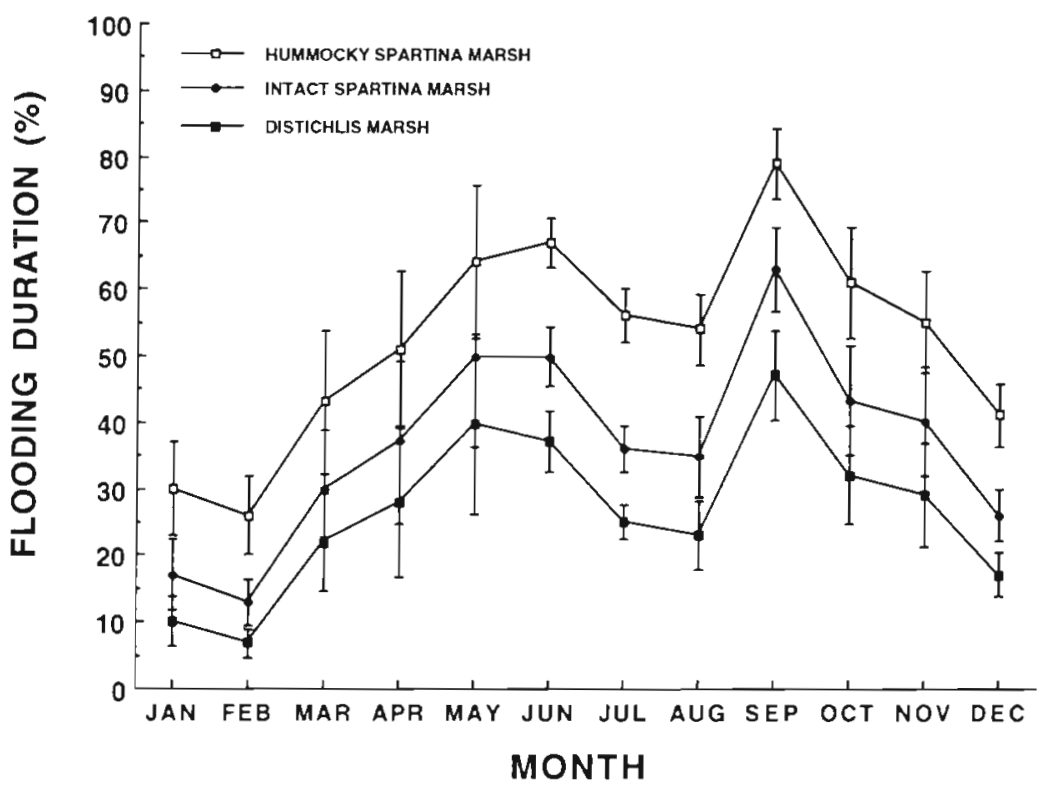

Fig. 5. Estimated 5 yr average monthly flooding durations [ (hours marsh inundated)/(total hours in month) $\times 100 /$ of Distichlis spicata, intact Spartina alterniflora, and hummocky S. alterniflora marshes for the period 1987 to 1991 Error bars = $1 \mathrm{SE}$ 
utilization on the Gulf coast. For example, densities of dominant species collected in our study and those reported by Zimmerman \& Minello (1984) are 1 to 2 orders of magnitude greater than those reported by Mense \& Wenner (1989) in South Carolina, by Hettler (1989) in North Carolina, and by Kneib (1991) and Fitz \& Wiegert (1991) in Georgia. Furthermore, Gulf coast marshes are flooded for long periods of time, especially during the late spring/early summer and fall. During 1991 Distichlis spicata, intact Spartina alterniflora, and hummocky $S$. alterniflora marshes in our study area were flooded 39,51 and $68 \%$ of the time, respectively. Sasser (1977) reported very similar mean annual flooding durations for S. alterniflora (54\%) and D. spicata (40\%) growing in coastal Louisiana. Based on 5 yr of data (Fig. 5), we estimate that maximum monthly flooding durations occurred in our hummocky $S$. alterniflora marshes in June (68\%) and September (78\%). Intact $S$. alterniflora marshes flooded $49.8,49.8$, and $61 \%$ of the time in May, June and September, respectively (Fig. 5). Similar maximum flooding durations of 75 and $80 \%$ were reported for salt marshes of Barataria Bay, Louisiana (Baumann 1980) and Galveston Bay, Texas (Zimmerman et al. 1991), respectively. However, lengthy flooding durations (annual mean $>50 \%$, maximum $=64$ to $74 \%$ in September) have also been recorded for some Atlantic coast marshes (D. L. Childers, National Marine Fisheries Service, Galveston Laboratory, pers. comm.). Unfortunately, hydroperiod data for coastal marshes are too limited, and the variation in flooding duration within marshes is so high, that comparisons of hydroperiod between the 2 regions are impossible to make at this time. Regional comparisons of marsh utilization and studies that examine the factors (including hydroperiod) that may influence differences in habitat use require further study.

Temporal variations in hydroperiod may also affect the abundance of marsh nekton. Seasonal changes in water levels explained most of the variability in brown shrimp collected on Galveston Bay salt marshes, and densities of white shrimp and blue crabs were also correlated with seasonal hydroperiods (Zimmerman \& Minello 1984). Likewise, highest densities of these decapods on our study marshes coincided with seasonally high water levels in the spring (brown shrimp) and fall (white shrimp and blue crab) (Table 3, Fig. 2). Marsh nekton populations may also be influenced by year-to-year variations in sea level. Commercial landings of penaeid shrimp and menhaden Brevoortia tyrannus (Latrobe) and $B$. patronus Goode have been correlated with interannual fluctuations in coastal water levels, suggesting a relationship between the degree of marsh flooding and productivity of these fisheries species (Childers et al. 1990, Morris et al.
1990). Evidence that brown shrimp grow faster and experience lower mortality rates when high water levels allow greater access to the marsh surface (Minello et al. 1989, Minello \& Zimmerman 1991) is consistent with these models

Although the most abundant species did not show a preference for hummocky Spartina alterniflora marsh over other marsh types, they probably occupy this habitat during low water periods when other habitats are not accessible. For example, grass shrimp and blue crab, which showed no significant habitat preference at high tide in our study (Fig. 4), exhibit strong selection for marsh vegetation when given a choice between unvegetated bottom and salt marsh (Zimmerman \& Minello 1984, Thomas et al. 1990). Gulf killifish and diamond killifish, which were associated with Distichlis spicata marsh at high tide (Fig. 4), apparently use the marsh surface whenever it is flooded (Hastings \& Yerger 1971, Lipcius \& Subrahmanyam 1986). In our study, gulf killifish were not constrained by shallow water in the $D$. spicata marsh; they were collected on marsh flooded $<5 \mathrm{~cm}$ deep, and their abundance was not related to water depth $\left(\mathrm{R}^{2}=0.038, \mathrm{p}=0.201\right)$. The other numerically dominant cyprinodonts exhibited similar behavior. Gulf killifish and diamond killifish undoubtedly use $S$. alterniflora marsh when it is first inundated but move onto higher $D$. spicata marsh when it becomes accessible later in the tidal cycle. Fundulus heteroclitus (Linnaeus) exhibit similar behavior on Atlantic coast marshes; they occupy intermediate and upper intertidal marsh at slack high tide, and occur in low intertidal marsh only on early advancing and late receding portions of the tidal cycle (Kneib 1976, 1984). However, for extended periods each month (during equatorial tides) when high marshes do not flood, killifishes and other marsh nekton must rely entirely on low S. alterniflora marshes. Gulf killifish and diamond killifish may be selecting $D$. spicata marsh when it is available because it contains high densities of favored prey, or perhaps the dense vegetation and shallow water found there provide added protection from predators. Adult killifishes may also use high marshes to locate suitable spawning sites (Greeley \& MacGregor 1983).

Gosselink (1984), Zimmerman et al. (1984), Browder et al. (1989), and others have postulated that coastal submergence enhances nekton access to Gulf coast marshes and secondary productivity, at least over the short term, by accelerating marsh disintegration and increasing the amount of marsh edge (marsh-water interface) in this region. However, coastal submergence also increases the percentage of time the marsh surface is available for use by aquatic species by lowering marsh-surface elevation and increasing hydroperiod. This may be especially beneficial to penaeid 
shrimp which seem to prefer low, deeply and frequently flooded Spartina alterniflora marshes that are in a late stage of submergence. The presence of low $S$. alterniflora marshes may be important for maintaining the high productivity of marsh nekton because they provide habitat during periods of low water when higher marshes are not flooded. However, the productivity of species that are dependent on marshes will surely begin to decline at some point in regions where the rate of submergence is high enough to cause a significant decrease in the total area of marsh habitat (Zimmerman et al. 1991).

Acknowledgements. We thank Thomas J. Minello, William Richards, Peter F. Sheridan, Roger J Zimmerman, and 2 anonymous reviewers for suggestions that improved the original manuscript. Marvin Goodly, Mark T. Jackson, and G. Scott Longman collected and processed most of the samples. James Donovan and Derral Dupre surveyed marsh elevations. Shanna Bonvillain and Tim Baumer drafted Fig. 1. Leasepermission was granted tor the use of marsh study sites by Louisiana Land and Exploration Company. This research was funded in part by a grant from the Coastal Ocean Program Office of the National Oceanic and Atmospheric Administration through Grant Number NA90AA-D SG779EHRP to the Louisiana Sea Grant College Program. The U.S. Government is authorized to produce and distribute reprints for governmental purposes, notwithstanding any copyright notation that may appear herein.

\section{LITERATURE CITED}

Baumann, R. H. (1980). Mechanisms for maintaining marsh elevation in a subsiding environment. M.Sc. thesis, Louisiana State University, Baton Rouge

Baumann, R. H., Day, J. W. Jr, Miller, C. A. (1984). Mississippi deltaic wetland survival: sedimentation vs. coastal submergence. Science 224: 1093-1095

Baumann, R. H., Delaune, R. D. (1982). Sedimentation and apparent sea-level rise as factors affecting land loss in coastal Louisiana. In: Boesch, D. F. (ed.) Proceedings of the conference on coastal erosion and wetland modification in Louisiana: causes, consequences and options. U.S. Fish and Wildlife Service, Biological Program, FWS/OBS82/59. Washington, DC, p. 2-13

Browder, J. A., May, L. N. Jr, Rosenthal, A., Gosselink, J. G., Baumann, R. H. (1989) Modeling future trends in wetland loss and brown shrimp production in Louisiana using thematic mapperimagery. Remote Sensing Environ. 28: 45--59

Chabreck, R. H., Linscombe, G. (1991). Louisiana coastal marsh vegetative type map, 1988, Terrebonne Bay. Louisiana Department of Wildlife and Fisheries, Baton Rouge

Childers, D. L., Day, J. W. Jr, Muller, R. A. (1990). Relating climatological forcing to coastal water levels in Louisiana estuaries and the potential importance of El Nin̄o-Southern Oscillation events. Clim. Res. 1. 31-42

Clark, J. S. (1986). Coastal forest tree populations in a changing environment, southeastern Long Island, New York. Ecol. Monogr. 56: 259-277

Coleman, J M., Gagliano, S. M. (1964). Cyclic sedimentation in the Mississippi River deltaic plain. Trans. Gulf Coast Ass. geol. Soc. 14:67-82
Dunbar, J. B., Britsch, L. D., Kemp, E. B. III (1992). Land loss rates: Report 3, Louisiana coastal plain. U.S. Army Corps of Engineers, Waterways Experiment Station, Technical Report GL-90-2, Vicksburg, MS

Fitz, H. C., Wiegert, R. G. (1991). Utilization of the intertidal zone of a salt marsh by the blue crab Callinectes sapidus. density, return frequency, and feeding habits. Mar. Ecol. Prog. Ser. 76: 249-260

Gornitz, V., Lebedeff, S., Hansen, J. E. (1982). Global sea level trend in the past century. Science 215: 1611-1614

Gosselink, J. G. (1984). The ecology of the delta marshes of coastal Louisiana: a community profile. U.S. Fish and Wildlife Service, FWS/OBS-84/09, Washington, DC

Greeley, M. S. Jr, MacGregor, R. III (1983). Annual and semilunar reproductive cycles of the gulf killifish. Fundulus grandis, on the Alabama Gulf coast. Copeia 1983: 711-71.8

Green, R. H. (1979). Sampling design and statistical methods for environmental biologists. John Wiley and Sons, New York

Hackney, C. T., Cleary, W. J. (1987). Salt marsh loss in southeastern North Carolina lagoons: importance of sea level rise and inlet dredging. J. coast. Res. 3: 93-97

Hastings, R. W., Yerger, R. W. (1971). Ecology and life history of the diamond killifish, Adinia xenica (Jordan and Gilbert). Am. Midl. Nat. 86: 276-291

Hatton, R. S., DeLaune, R. D., Patrick, W. H. (1983). Sedimentation, accretion and subsidence in marshes of Barataria Basin, Louisiana. Limnol. Oceanogr. 28: $494-502$

Hettler, W. F. (1989). Nekton use of regularly-flooded saltmarsh cordgrass habitat in North Carolina, USA. Mar. Ecol. Prog. Ser. 56: 111-118

Hopkinson, C. S., Gosselink, J. G., Parrondo, R. T. (1978) Aboveground production of seven marsh plant species in coastal Louisiana. Ecology 59: 760-769

Kneib, R. T. (1976). Feeding, reproduction, growth and movements of killifishes on a North Carolina salt marsh. M.A. thesis, Univ. of North Carolina, Chapel Hill

Kneib, R. T. (1984). Patterns of invertebrate distribution and abundance in the intertidal salt marsh: causes and questions. Estuaries 7: 392-412

Kneib, R. T (1991). Flume weir for quantitative collection of nekton from vegetated intertidal habitats. Mar. Ecol. Prog. Ser. 75: 29-38

LaSalle, M. W., Rozas, L. P. (1991). Comparing benthic macrofaunal assemblages of creekbank beds of the spikerush Eleocharis parvula (R \& S) Link and adjacent unvegetated areas in a Mississippi brackish marsh. Wetlands 11: $229-244$

Linthurst, R. A., Seneca, E. D. (1980). The effects of standing water and drainage potential on the Spartina alterniflorasubstrate complex in a North Carolina salt marsh. Estuar coast. mar. Sci. 1.1: 41-52

Lipcius, R. N., Subrahmanyam, C. B. (1986). Temporal factors influencing killifish abundance and recruitment in Gulf of Mexico salt marshes. Estuar. coast. Shelf Sci. 22: 101-114

McIvor, C. C., Odum, W. E. (1988). Food, predation risk, and microhabitat selection in a marsh fish assemblage Ecology 69: 1341-1351

Mendelssohn, I. A., McKee, K. L. (1988). Spartına alterniflora die-back in Louisiana: time course investigations of soil waterlogging effects. J. Ecol. 76: 509-521

Mendelssohn, I. A., Seneca, E. D. (1980). The influence of soil drainage on the growth of salt marsh cordgrass Spartina alterniflora in North Carolina. Estuar. coast. mar. Sci. 11. $27-40$

Mense, D. J., Wenner, E. L. (1989). Distribution and abun- 
dance of early life history stages of the blue crab, Callinectes sapidus, in tidal marsh creeks near Charleston, South Carolina. Estuaries 12: 157-168

Minello, T J., Zimmerman, R. J. (1983). Fish predation on juvenile brown shrimp, Penaeus aztecus Ives: the effect of simulated Spartina structure on predation rates. I exp. mar. Biol. Ecol. 72: 211-231

Minello, T J., Zimmerman, R. J. (1991). The role of estuarine habitats in regulating growth and survival of juvenile penaeid shrimp. In: DeLoach, P., Dougherty, W. J., Davidson, M. A. (eds.) Frontiers of shrimp research. Elsevier Science Publishers, Amsterdam, p. 1-16

Minello, T J., Zimmerman, R. J., Martinez, E. X. (1989). Mortality of young brown shrimp Penaeus aztecus in estuarine nurseries. Tran. Am. Fish. Soc. 118: 693-708

Morris, J. T., Kjerfve, B., Dean, J. M. (1990). Dependence of estuarine productivity on anomalies in mean sea level. Limnol. Oceanogr. 35: 926-930

Norusis, M. J. (1990). SPSS advanced statistics user's guide SPSS Inc., Chicago

O'Brien, R. G., Kaiser, M.K. (1985). MANOVA method for analyzing repeated measures designs: an extensive primer Psychol. Bull. 97: 316-333

Penland, S., Ramsey, K. E. (1990). Relative sea-level rise in Louisiana and the Gulf of Mexico: 1908-1988. J. coast. Res. 6: 323-342

Rader, D. N. (1984). Salt-marsh benthic invertebrates: smallscale patterns of distribution and abundance. Estuaries 7 $413-420$

Reed, D. J., Cahoon, D. R. (1992). The relationship between marsh surface topography, hydroperiod, and growth of Spartina alterniflora in a deteriorating Louisiana salt marsh. J. coast. Res. 8: 77-87

Rice, W. R. (1989). Analyzing tables of statistical tests Evolution 43: 223-225

Rozas, L. P. (1992a). Bottomless lift net for quantitatively sampling nekton on intertidal marshes. Mar. Ecol. Prog. Ser 89: $287-292$

Rozas, L. P. (1992b). Comparison of nekton habitats associated with pipeline canals and natural channels in Louisiana salt marshes. Wetlands 12: 136-146

Rozas, L. P., Odum, W. E. (1987). Use of tidal freshwater marshes by fishes and macrofaunal crustaceans along a marsh stream-order gradient. Estuaries 10:36-43

Sasser, C. E. (1977). Distribution of vegetation in Louisiana

This article was presented by G. W. Thayer, Beaufort, N. Carolina, USA coastal marshes as response to tidal flooding. M.Sc. thesis, Louisiana State University, Baton Rouge

Sasser, C. E., Dozier, M. D., Gosselink, J. G., Hill, J. M. (1986). Spatial and temporal changes in Louisiana's Barataria Basin marshes, 1945-1980. Environ. Mgmt 10:671-680

Shirzad, F. F., Klein, C. J. III, Orlando, S. P. Ir (1989). Revised physical and hydrologic characteristics for the Mississippi Delta Region estuaries. NOAA National Ocean Service, Rockville, MD

Smith, W. G. (1970). Spartina 'die-back' in Louisiana marshlands. In: Coastal Studies Bulletin No. 5. Louisiana State University, Baton Rouge, p. 89-96

Stevenson, J. C., Ward, L. G., Kearney, M. S. (1986). Vertical accretion in marshes with varying rates of sea level rise. In: Wolfe, D. A. (ed.) Estuarine variability. Academic Press, Orlando, p. 241-259

Thomas, J. L., Zimmerman, R. J., Minello, T J. (1990). Abundance patterns of juvenile blue crabs (Callinectes sapidus) in nursery habitats of two Texas bays. Bull. mar. Sci. 46: $115-125$

U.S. Department of Commerce (1990). Tide tables 1991 (high and low water predictions) east coast of North and South America, including Greenland. NOAA National Ocean Service, Rockville, MD

Van Dolah, R. F. (1978). Factors regulating the distribution and population dynamics of the amphipod (Gammarus palustris) in an intertidal salt marsh community. Ecol. Monogr. 48: 191-217

Vince, S., Valiela, I., Backus, N., Teal, J. M. (1976). Predation by the salt marsh killifish Fundulus heteroclitus $\mathrm{L}$. in relation to prey size and habitat structure: consequences for prey distribution and abundance. J. exp. Mar. Biol. Ecol. 23: $255-266$

Zimmerman, R. J., Minello, T J. (1984). Densities of Penaeus aztecus, Penaeus setiferus, and other natant macrofauna in a Texas salt marsh. Estuaries 7: 421-433

Zimmerman, R. J., Minello, T J., Klima, E. F., Nance, J. M. (1991). Effects of accelerated sea-level rise on coastal secondary production. In: Bolten, H. S., Magoon, O. T (eds.) Coastal wetlands. Coastal Zone '91 Conference. Am. Soc. Civil Eng., New York, p. 110-124

Zimmerman, R. J., Minello, T J., Zamora, G. Jr (1984). Selection of vegetated habitat by brown shrimp, Penaeus aztecus, in a Galveston Bay salt marsh. Fish. Bull. U.S. 82: $325-336$

Manuscript first received: November 23, 1992

Revised version accepted: March 11, 1993 